\title{
WHAT RESPONSIBILITIES DO SOVEREIGN FUNDS HAVE TO OTHER INVESTORS?
}

\author{
Paul Rose*
}

\section{INTRODUCTION}

With trillions of dollars in assets, sovereign wealth funds ("SWFs") play a major role in financial markets around the world. With billions of (and probably well over a trillion) dollars' worth of equity investments around the world, ${ }^{1}$ the investment behavior of SWFs is of primary concern to regulators, portfolio firms, and other investors. The routinely cited perils of sovereign investment, such as politicization, corporate espionage, and mercantilism, are typically seen as emanating from equity investments by SWFs. ${ }^{2}$ On the other hand, SWFs offer the promise of patient, sustainable investment by engaged stewards who take a long view of the impact of their investments.

This Article seeks to provide a realistic appraisal of the benefits and potential costs of SWF investment for other investors. Most work on SWF investment has focused on the challenges that SWFs present to regulators, portfolio companies, or their own domestic constituencies. $^{3}$ Although a few studies have examined SWF investment price impacts, ${ }^{4} \mathrm{SWF}$ analyses have tended to ignore the effect of SWF investment on other investors. What, if anything, do

* Bazler Designated Professor in Business Law, Moritz College of Law, Ohio State University.

1. Sudip Kar-Gupta, Sovereign Funds' Selling Could Hit $\$ 700$ Bln of European Stocks, REUTERS (Feb. 10, 2016, 10:51 AM), http://www.reuters.com /article/europe-stocks-sovereign-idUSL8N15O3WX (citing J.P. Morgan analyst Nikolaos Panigirtzoglou's estimate that "oil producers' funds hold around $\$ 2$ trillion of publicly listed equities worldwide").

2. See, e.g., Paul Rose, Sovereign Investing and Corporate Governance: Evidence and Policy, 18 FordhAM J. CoRP. \& FIN. L. 913, 920, 946 (2013) [hereinafter Rose, Sovereign Investing and Corporate Governance].

3. See, e.g., Simone Mezzacapo, The So-called "Sovereign Wealth Funds": Regulatory Issues, Financial Stability and Prudential Supervision, in EUROPEAN ECONOMY (European Comm'n, Directorate Gen. for Econ. \& Fin. Affairs, Economic Papers No. 378, 2009), http://ec.europa.eu/economy_finance /publications/pages/publication15064_en.pdf.

4. See, e.g., Jason Kotter \& Ugur Lel, Friends or Foes? Target Selection Decisions of Sovereign Wealth Funds and Their Consequences, 101 J. FIN. ECON. 360 (2011). 
SWFs owe to other investors? This Article calls for sovereign investors to recognize the special responsibilities they have to coinvestors. While these responsibilities may not constitute actionable fiduciary duties, SWFs should embrace a model of transparent, engaged ownership that will benefit their co-investors and their common portfolio companies.

This Article first outlines the concept of fiduciary duties generally and describes the way that such duties (or their civil law equivalents) impact SWF governance. Next, it addresses the complex question of the object of SWF duties. The sponsor government, at least, has claim to these duties, but what of other impacted constituencies, such as citizens? This Article then turns to the issue of investor obligations and notes that while investors typically do not owe one another fiduciary duties, they can mutually benefit by minimizing costs for one another through adhering to basic principles of transparency and predictable investment behavior. Lastly, this Article evaluates the ability of the Santiago Principles to encourage this kind of transparency and predictability through a review of recently completed SWF self-assessments of compliance with the Santiago Principles.

\section{SOVEREIGN WEALTH FUndS AND FIDUCIARY DUTY}

The idea of "fiduciary duties" as a standard of conduct for investment managers is well known in the Western world, particularly in common law jurisdictions. In the United States, for example, the 1830 case Harvard College v. Armory5 required trustees "to observe how men of prudence, discretion and intelligence manage their own affairs ...."6 Later, the Restatement (Third) of Trusts updated the standard to require a trustee to "administer the trust as a prudent person would, in light of the purposes, terms, and other circumstances of the trust[.]" 7 with "reasonable care, skill, and caution." 8 Trustees are bound not only by this duty of care but also by a strict duty of loyalty that requires them to "administer the trust solely in the interest of the beneficiaries,"9 prohibits self-dealing transactions, ${ }^{10}$ and obligates fair dealing and full disclosure of "all material facts the trustee knows or should know" to the beneficiaries. ${ }^{11}$

\footnotetext{
5. 26 Mass. (9 Pick.) 446 (1830).

6. Id. at 461 .

7. RESTATEMENT (THIRD) OF TRUSTS $\S 77(1)$ (AM. LAW. INST. 2007).

8. Id. $\S 77(2)$.

9. Id. $\S 78(1)$.

10. Id. $\S 78(2)$.

11. Id. $\S 78(3)$.
} 
Fiduciary duties-if not in name, at least in effect-are not unique to the West. The roots of modern-day fiduciary duties run deep and wide, through "[a]lmost every ancient law across many different [civilizations] ...."12 One finds these roots stretching back to medieval English trust law, fifth-century Islamic family law, fourth-century Roman inheritance law, the teachings of Confucius (551-479 BC), and the Code of Hammurabi (circa $1790 \mathrm{BC}$ ). ${ }^{13}$ Yet outside of common law jurisdictions, one is less likely to refer to "fiduciary obligations" as such. For example, what one might label a fiduciary duty in a common law jurisdiction may be defined by a civil law jurisdiction as a contractual or statutory arrangement due to their imposition of similar obligations. ${ }^{14}$ As stated in a European Union report:

Common law jurisdictions tend to operationalize fiduciary relationships through trusts and provide greater interpretive discretion to judges, while civil law countries are likely to use a contractual arrangement with a financial institution or management company and focus more on specific regulatory guidance than principles. This does not mean that fiduciary duty does not exist in civil law. The concept of fiduciary duty is present in the legislation of every EU Member State as similar specific obligations to institutional investors. ${ }^{15}$

SWFs, defined here as special purpose investment funds that are owned by the general government, ${ }^{16}$ are generally non-Western entities created in jurisdictions that do not have a common law tradition of fiduciary duty. This fact appears to be reflected in the recent self-assessments of compliance with the Santiago Principles (or, as the Santiago Principles are more formally known, the Generally Accepted Principles and Practices). ${ }^{17}$ While not referring explicitly to fiduciary duties, Principle 8 states that "[t]he governing body(ies) should act in the best interests of the SWF, and have a

12. ERIC MUGNiER ET AL., Resource EFFICIENCY AND FIdUCIARY Duties of INVESTORS 22 (2014), http://ec.europa.eu/environment/enveco/resource_efficiency /pdf/FiduciaryDuties.pdf.

13. KeITh L. JohnSon, InT'L Inst. For SUstainable DeV., InTRODUCTION to INSTITUTIONAL INVESTOR FIDUCIARY DUTIES 2 (2014), http://www.reinhartlaw.com/wp-content/uploads/2016/01/Introduction-to

-Institutional-Investor-Fiduciary-Duties.pdf.

14. MUGNIER ET AL., supra note 12 , at 8.

15. Id. at 22 .

16. This definition, set out by the International Working Group of Sovereign Wealth Funds, is not uncontested. See, e.g., JAVIER CAPAPÉ \& TOMÁS GUERRERo, MORE LAYERS THAN AN ONION: LOOKING FOR A DEFINITION OF SOVEREIGN WEALTH FUNDS 2 (2013), http://fletcher.tufts.edu/SovereigNet /Research/More-Layers-Than-an-Onion.

17. Id. at 8 . 
clear mandate and adequate authority and competency to carry out its functions." 18 Of the twenty-nine funds that provided selfassessments, only three mentioned the term "fiduciary" at all in their discussion of how they comply with Principle 8.19 Searching for explicit "fiduciary duties" in the publicly available policies governing SWF managers' conduct also produces few results. Of the twenty-five largest SWFs in the world, only eight disclose that they follow some sort of fiduciary duty or prudent investor standard. ${ }^{20}$ Even of these eight, only a few operationalize what a U.S. investment manager would recognize as U.S.-style fiduciary duties. 21

Even if not explicitly adopting fiduciary standards, many, if not all, SWFs operate in accordance with the basic tenets of loyalty and due care that underlie the Western conceptualization of fiduciary duty. China Investment Corporation ("CIC"), for example, states that it "is committed to being a prudent, professional and responsible institutional investor operating globally with good reputation." 22 It operates in accordance with four principles:

- [I]nvest on a commercial basis ... [and] seek maximum returns for [its] shareholder [the Chinese government] within acceptable risk tolerance.

- [Act as] a financial investor and do not seek control of [portfolio companies].

- $\quad$ Act as] a responsible investor, abiding by the laws and regulations of China and recipient countries and consciously fulfilling ... corporate social responsibilities.

- $\quad[P]$ ursue investments based on in-depth research within [its] asset allocation framework to ensure a prudent and disciplined decision-making process. ${ }^{23}$

18. InT'L Working GrP. OF SOVEREIGN Wealth FUndS, SOVEREign Wealth FundS: GeNerally ACCEPTEd PRINCIPLES ANd PRACTICES: "SANTIAGo PRINCIPLES" 7 (2008) [hereinafter SANTIAGO PRINCIPLES], http://www.ifswf.org/sites/default /files/santiagoprinciples_0_0.pdf.

19. The three funds are the Agaciro Development Fund (Rwanda), Kazanah Nasional Berhad (Malaysia), and the Pula Fund (Botswana). See Santiago Principle Self-Assessments, INT'L F. SOVEREIGN WEALTH FUNDS, http://www.ifswf.org/assessments (last visited Oct. 25, 2017).

20. Paul Rose, Public Funds Investment Policies: 2016 Survey 10 (Ohio State Pub. Law, Working Paper No. 376, 2017), https://papers.ssrn.com/sol3 /papers.cfm?abstract_id=2917871 [hereinafter Rose, Public Funds Investment Policies: 2016 Survey].

21. Id.

22. Investment Philosophies, CHINA INV. CoRP., http://www.china-inv.cn/wps /portal/ (last visited Oct. 15, 2017) (select "EN" for English, then follow "Investments" and "Investment Philosophies" hyperlinks to access source).

23. Id. 
One could characterize a "prudent" and "disciplined decisionmaking process" and a focus on maximum returns as creating a similar obligation to the core fiduciary duties of care and loyalty. The general animus of fiduciary duties in common law jurisdictions is to limit the agency costs of vulnerable beneficiaries by requiring strict standards of conduct for fiduciaries. ${ }^{24}$ Similarly, fiduciary duties limit the information asymmetries between the principalbeneficiaries and the agent-trustees. ${ }^{25}$ In the general case in which fiduciary duties are written in by the law as a standard form contract, efficiency dictates that the government-through common law or by statute-supply that standard contract. Beneficiaries face risks relative to the trustee, such as a lack of information or the ability to understand the information received or a collective action problem that impairs the ability of a group of beneficiaries from adequately monitoring a trustee. These typical concerns may seem to be mitigated when the beneficiary is a sophisticated sovereign. For example, one might expect that the Chinese government is quite capable of policing agency costs within the CIC. Yet conflicts of interest, shirking, and corruption can arise even in well-managed funds, ${ }^{26}$ and fiduciary duties (or their statutory equivalents) can play an important role in setting out appropriate standards of conduct as well as penalties for failure to meet the standards. ${ }^{27}$

Thus far, this Article has noted how most SWFs do not operate under a common law tradition that imposes fiduciary duties on trustees. However, SWFs generally do employ governance structures that require diligence in how investments are selected, accountability for investment outcomes, and restrictions on transactions that have the potential to create a conflict of interest. 28 Whether fiduciary-like obligations are created by the courts, statutes, rules, or procedures of the SWF, the governance output may be the same. The differences in governance quality do not depend so much on the type of structure as much as the quality of the institutions that monitor and enforce fund governance. But regardless of the mechanisms that supply the governance-the "how" of fund governance-we must still ask, as Justice Frankfurter

24. See Tamar Frankel, 2 The New Palgrave Dictionary of Economics AND THE LAW 127-28 (defining "fiduciary duties").

25. Id.

26. See, e.g., Philipp Hildebrand, The Challenge of Sovereign Wealth Funds, VOX (Jan. 21, 2008), http://voxeu.org/article/challenge-sovereign-wealth-funds.

27. FRANKEL, supra note 24.

28. See Rose, Public Funds Investment Policies: 2016 Survey, supra note 20, at 12 . 
did, the "who" questions of fund governance: For whom does the fund manager work? To whom does the fund manager owe duties? ${ }^{29}$

An initial answer is that the fund should be managed on behalf of the government. However, this question can be surprisingly complicated as one asks whether the government is, in turn, an intermediary merely managing on behalf of another group. For example, does the government manage the fund on behalf of the elites? Hatton and Pistor argue that, in the case of many SWFs, "the ruling elite utilize SWFs to secure their domestic political dominance against both internal and external threats." 30

Alternatively, a government may manage the fund assets on behalf of its people as a "fiduciary state." 31 Who are the "people" that are the beneficiaries of this management? Citizens? Residents? Voters? Taxpayers? Current and future generations, or just future generations, seeing as some SWFs are designed to compensate future generations for the loss of income from the current generation's sale of natural resources? The very concept of a fiduciary state is controversial. Normally, one thinks of fiduciary duties in an investment context as existing to "ensure that those who manage other people's money act in the interests of beneficiaries."32 But is sovereign wealth the wealth of the people?

The issue has arisen in the United States after the State of Alaska decided to tax the dividend checks paid to Alaskan citizens out of the Alaska Permanent Fund's returns. ${ }^{33}$ The Alaska Permanent Fund was created in 1976 to invest a portion of the income generated from all mineral lease rentals, royalties, and other related payments received by the state. ${ }^{34}$ At issue in Beattie $v$. United States ${ }^{35}$ was whether the state could tax a dividend paid out of income generated from such proceeds. 36 The plaintiff-citizen argued that the dividend payments are "neither the fruits of labor or capital, nor are they 'income' in the layman's sense of the word" and

29. Sec. \& Exch. Comm'n v. Chenery Corp., 318 U.S. 80, 85-86 (1943) ("To say that a man is a fiduciary only begins analysis; it gives direction to further inquiry. To whom is he a fiduciary? What obligations does he owe as a fiduciary? In what respect has he failed to discharge these obligations? And what are the consequences of his deviation from his duty?").

30. Kyle Hatton \& Katharina Pistor, Maximizing Autonomy in the Shadow of Great Powers: The Political Economy of Sovereign Wealth Funds, 50 CoLUM. J. TRANSNAT'L L. 1, 1, 3 (2011).

31. See Dan Purves, Sovereigns Versus Citizens, Top1000funds.com (Apr. 20, 2017), https://www.top1000funds.com/analysis/2017/04/20/sovereigns-versus -citizens/.

32. MUGNIER ET AL., supra note 12, at 19.

33. Beattie v. United States, 635 F. Supp. 481, 484 (D. Alaska 1986).

34. Id. at 482 .

35. 635 F. Supp. 481 (D. Alaska 1986).

36. Id. at 485 . 
that "the Permanent Fund dividend payments are not from an outside or third-party source since it is the people's natural resources ...."37 The U.S. District Court for the District of Alaska was not convinced. It held that

[n] either the resources in question, nor the proceeds from the same, nor the income from those proceeds, are the "property" of any person who resides in the State of Alaska. As [plaintiff] argues, the people in some very real sense do have ultimate sovereignty and are the ultimate masters of the state. But that does not make the people the "owners" of that property which is the subject of this discussion. In adopting their constitution, the people of the State of Alaska have very clearly constituted the state as owner of the natural resources which give rise to the fund in question. ${ }^{38}$

However, the fact that the State of Alaska, rather than the people of Alaska, was held to "own" the property in question does not necessarily negate the fiduciary character of the state. For example, although one typically sees a fiduciary managing property owned by the beneficiary - such as the management of a retirement account by an investment manager-this is not always the case. One would not consider the pension fund beneficiary to own the underlying assets managed on her behalf by a pension fund trustee, yet it is without question that the trustee owes fiduciary duties to the pensioner. ${ }^{39}$ The court in Beattie noted that language in the Alaska Constitution stressed the state's ownership rights ${ }^{40}$ but also cited section 2, which mandates that "[t]he legislature shall provide for the utilization, development, and conservation of all natural resources belonging to the State, including land and waters, for the maximum benefit of its people." 41 Although the property may not be owned by the people-and so the fiduciary relationship between the sovereign and the people may not be as direct as that of an investment manager managing other people's money-the state may still be considered a fiduciary in the same way that a corporate pension fund's trustees are the fiduciaries of the fund's beneficiaries. 42

37. Id. at 491 .

38. Id.

39. Id. at 489 .

40. Id. at 491 (citing AlaskA CONST. art. VIII, $\S 1$ ("It is the policy of the State to encourage the settlement of its land and the development of its resources by making them available for maximum use consistent with the public interest." (emphasis added))).

41. Id. at 491-92 (citing ALASKA CONST, art. VIII, § 2).

42. Whether a public pension fund is a fiduciary in the same sense as a corporate fund is not a simple question and is discussed in detail in Paul Rose, 
The argument for SWFs and their state sponsors as fiduciaries has been made forcefully by Cummine, who contends that governments, as creators and sponsors of SWFs, should be subject to a fiduciary-like obligation to "act in the interests of the domestic community in establishing, managing and using an SWF." 43 SWFs should guard against conflicts of interest, and "[a]ny attempt by government or state agencies to exert control over sovereign wealth in a manner that serves their own interests (or the interests of some narrowly defined group within a domestic community) rather than the interests of the community at large would be inimical to this principle." 44 Cummine's principle of a fiduciary state thus runs counter to Hatton and Pistor's explanation that SWFs exist to maximize the interests of the elite. 45

The fiduciary-state model of SWF governance does not resolve the central question of this Article- what responsibilities do SWFs have to other investors-but, as will be discussed in subsequent Parts, the governance mechanisms it engenders have a deep impact on the ability of other investors to monitor and evaluate SWF behavior. The concept of the SWF as a mechanism of the fiduciary state focuses on a view that SWFs have responsibilities to citizens that should shape their governance policies and processes. This Article seeks to expand that view to show that although SWFs may only be bound strictly to their sponsor government in terms of actionable duties (excepting, of course, legal duties arising from their voluntary participation in markets), ${ }^{46}$ they are yet tied to many other constituencies in ways that imply important responsibilities for SWFs if they are to develop as long-term, trusted investors in international markets. The governance policies and processes that benefit citizen-beneficiaries also serve to benefit the SWF's co-investors.

Public Wealth Maximization: A New Framework for Public Fund Fiduciary Duties, 2018 U. ILL. L. REV. (forthcoming 2018) (concluding that public pension funds owe duties to the state and the public generally rather than merely to individual beneficiaries).

43. ANGEla Cummine, Citizens' Wealth: Why (AND How) SOVEREIGN FundS Should Be Managed by The People for The People 55-56 (2016).

44. Id.

45. Note, however, that Hatton and Pistor are making a descriptive claim, rather than a normative claim. Cummine's claim may be descriptive for some funds, but it is intended as a normative claim for SWFs, generally.

46. See Ingilab Ahmadov et al., Sovereign Wealth Funds As the Emerging Players in the Global Financial Arena: Characteristics, Risks and Governance, in Sovereign Wealth Funds: New Challenges for the Caspian CounTries 6 , 10-14 (2011), https://resourcegovernance.org/sites/default/files/SWFs-Caspian -Countries.pdf. 


\section{WHAT Do INVESTORS OWE ONE ANOTHER?}

Before asking what SWFs might owe to other investors, we must first briefly outline what the law says generally about investors' duties. It is well-accepted under U.S. law that shareholders have the right to selfish ownership of their shares. ${ }^{47}$ In limited circumstances, however, the law holds certain investors to a high standard. ${ }^{48}$ In particular, "controlling insiders are fiduciaries toward the non-controlling shareholders in regard to the manner in which control is exercised." 49 Even this doctrine has limits, however. As Bainbridge notes, "while corporate law ensures that the majority may not benefit itself at the expense and to the exclusion of the minority, corporate law does not require the majority affirmatively to benefit the minority at its own expense. There simply is no corporate law version of affirmative action." 50

But what about non-controlling shareholders? We assume that they are free to buy, sell, and vote however they choose and do not owe any duty to other shareholders. Because they do not control the corporate machinery, there would seem to be no general concern that they could use the resources of the corporation to benefit themselves at the expense of the remaining shareholders-a core (if not the core) concern in corporate law. ${ }^{51}$ Other scholars have argued otherwise. In an influential article, Anabtawi and Stout suggest that as shareholders become more active in corporate governance, more attention should be paid to both the manner in which they exercise their influence and the goals that they are trying to achieve:

[E]ven as shareholders are becoming more powerful, their interests are becoming more heterogeneous. Increasingly, the economic interests of one shareholder or shareholder group conflict with the economic interests of others. The result is

47. See, e.g., Med. Air Tech. Corp. v. Marwan Inv., Inc., 303 F.3d 11, 21 (1st Cir. 2002); Butler v. Moore, No. 10-10207-FDS, 2015 WL 1409676, *60 (D. Mass. Mar. 26, 2015); Pointer v. Castellani, 918 N.E.2d 805, 816 (Mass. 2009).

48. See Alfred Hill, The Sale of Controlling Shares, 70 HARV. L. REv. 986, 1034 (1957); see also A.A. Berle, Jr., Corporate Powers as Powers in Trust, 44 HaRv. L. REV. 1049, 1049 (1931); Daniel S. Kleinberger, Donahue's Fils Aîné: Reflections on Wilkes and the Legitimate Rights of Selfish Ownership, $33 \mathrm{~W}$. New ENG. L. Rev. 405, 409-10 n.22, 412-13 (2011).

49. Hill, supra note 48 , at 1014 .

50. Stephen M. Bainbridge, There Is No Affirmative Action for Minorities, Shareholder and Otherwise, in Corporate Law, 118 YALE L.J. PoCKET PART 71, 75 (2008).

51. See, e.g., In re USACafes, L.P. Litig., 600 A.2d 43, 48 (Del. Ch. 1991) ("[O]ne who controls property of another may not, without implied or express agreement, intentionally use that property in a way that benefits the holder of the control to the detriment of the property or its beneficial owner."). 
that activist shareholders are using their growing influence not to improve overall firm performance, as has generally been assumed, but to profit at other shareholders' expense. ${ }^{52}$

In other work, I have argued in support of the view that shareholders have heterogeneous interests and will often pursue interests that are adverse to other shareholders. ${ }^{53}$ This problem can be highlighted by focusing on the various agency relationships at work in corporations. Let us first assume that the corporation in question is a large, publicly traded corporation with a wide group of shareholders, including both retail and institutional investors. The primary agency and duty relationship at work in the corporation is that of managers (by which I mean both directors and senior corporate officers) to shareholders. ${ }^{54}$ These shareholders will likely include a variety of institutional investors, including pension funds, insurance companies, mutual funds, retail investors, and perhaps even hedge fund investors. ${ }^{55}$

52. Iman Anabtawi \& Lynn A. Stout, Fiduciary Duties for Activist Shareholders, 60 STAN. L. REV. 1255, 1258 (2008).

53. See generally Paul Rose, Common Agency and the Public Corporation, 63 VAND. L. REv. 1353 (2010) [hereinafter Rose, Common Agency and the Public Corporation].

54. I acknowledge but do not discuss the potential concern that a board of directors is not, as Stephen Bainbridge notes, a "mere agent of the shareholders, but rather is a sui generis body-a sort of Platonic guardianserving as the nexus of the various contracts making up the corporation." Stephen M. Bainbridge, Director Primacy: The Means and Ends of Corporate Governance 6 (UCLA, Sch. Of Law, Research Paper No. 02-06, 2002), https://papers.ssrn.com/sol3/papers.cfm?abstract_id=300860. This characterization may be a fair reading of some Delaware precedent yet fails to take in account the clear signaling by Delaware courts that corporations are to be managed for the benefit of shareholders. No less an authority than Delaware Supreme Court Justice Leo Strine states that "the corporate law requires directors, as a matter of their duty of loyalty, to pursue a good faith strategy to maximize profits for the stockholders." Leo E. Strine, Jr., Our Continuing Struggle with the Idea that For-Profit Corporations Seek Profit, 47 WAKE FOREST L. REV. 135, 155 (2012). The continuing focus on aligning interests in compensation arrangements is, in practice, designed to support this notion. As a descriptive (and not normative) matter, it would seem increasingly challenging to sustain the view that directors do not function as the agents of shareholders.

55. Strine, supra note 54, at 144. 


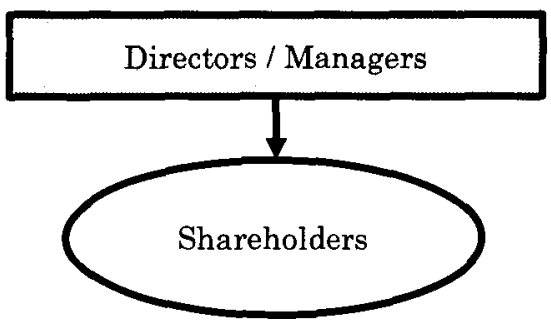

A standard representation of this relationship, as shown above, has the managers, as agents, serving the shareholders as a group. In this simple formulation, the flow of fiduciary duties appears uncomplicated and linear. In the modern corporation, however, the relationship is more complex. We can accentuate these complexities by focusing on the influence of the various principals-the shareholders -on the managers.

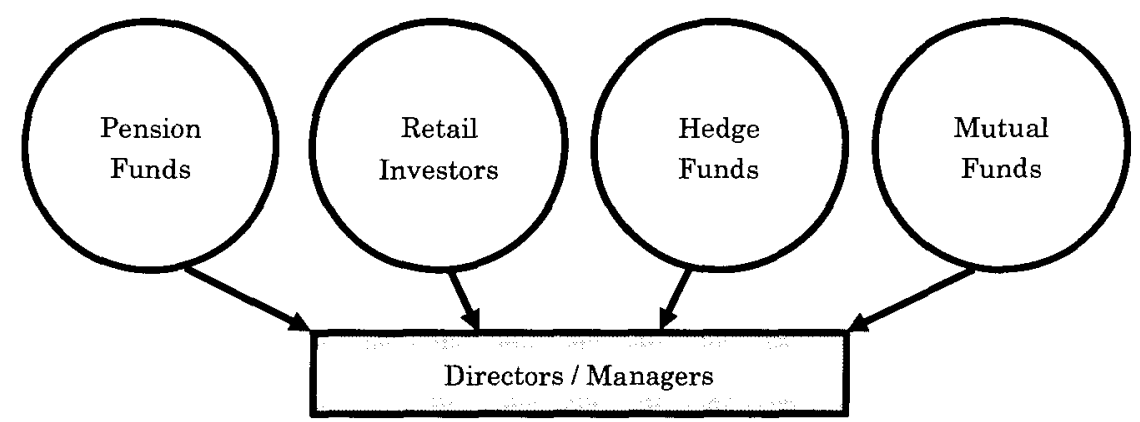

If we believe, as Anabtawi and Stout argue, 56 that shareholders and other constituencies often have heterogeneous interests (even though they may also share, in most cases, a desire to maximize profits), then we can see the shareholders not as a single principal with a unitary goal but as a group of independently minded principals sharing a common agent. This common agency problem creates several concerns. First, managers must deal with competing (and perhaps conflicting) interests among influential shareholders. To whom will they listen? Second, how will shareholders be able to track and counter the influence of other shareholders with competing views?

We may also note that SWFs and other large institutional investors may have their own common agency concerns. For

56. Anabtawi \& Stout, supra note 52. 
example, SWFs-the common agent-may be thought to have multiple principals, as shown in the following paired possibilities:

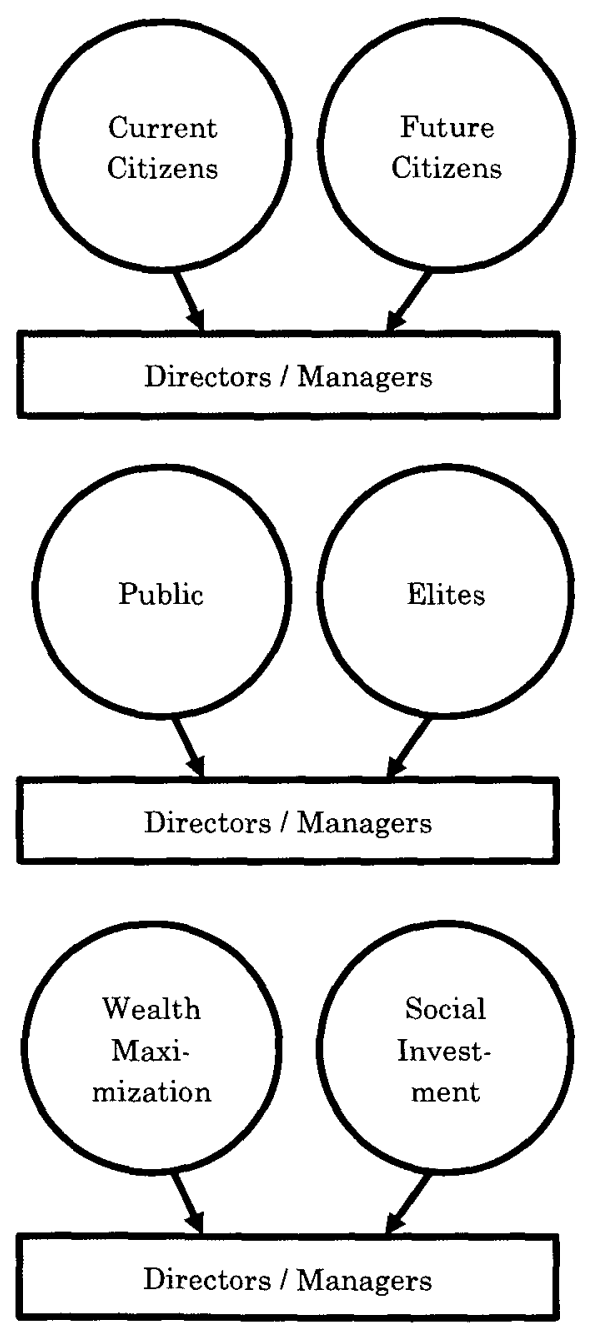

To summarize, modern corporate law must deal with two separate concerns: The first is the traditional agency-cost concern that tries to monitor or bind management to limit the residual costs of agent shirking or misappropriation. ${ }^{57}$ The second set of agency costs-common agency costs-arise as shareholders must monitor or

57. Michael C. Jensen \& William H. Meckling, Theory of the Firm: Managerial Behavior, Agency Costs and Ownership Structure, 3 J. Fin. ECoN. 305, 308-09 (1976) (popularizing the basic agency cost framework). 
bind other shareholders to limit the residual costs of their influence, potential conflicts of interest, and potential misappropriation. ${ }^{58}$

The common agency problem is readily apparent in the context of SWF investment, although as time passes some of these concerns are somewhat allayed.59 In the early stages of conspicuous SWF investment in U.S. markets-around the time of the financial crisis-commentators focused particularly on the risk that investments would be used for political purposes, rather than financial or commercial purposes.60 In a seminal article, Robert Kimmitt, Deputy Secretary of the U.S. Department of the Treasury, described the primary issues as follows:

First, do [SWFs] perpetuate undesirable underlying macroeconomic policies? Countries should not use them as a mechanism to accumulate more foreign assets to avoid exchange rate appreciation. Second, what is the potential impact of these funds on financial stability? SWFs are in principle long term, stable investors who can provide liquidity to the markets. However, they also represent large, concentrated-and often non-transparent-positions in financial markets. Third, are SWF investment decisions made on commercial grounds consistent with the free market principles? Finally, do investment decisions by SWFs have national security implications? ${ }^{61}$

All of these concerns remain, although a web of federal regulations and market constraints help mitigate some risks. ${ }^{62}$ Some of the concerns are monitored through high-level government review of SWF transactions, ${ }^{63}$ but some-such as whether SWFs perpetuate harmful macroeconomic effects or pose risks to financial stability-are not easily managed because they implicate the political and economic calculations of a sovereign entity. ${ }^{64}$

58. Id.

59. Rose, Common Agency and the Public Corporation, supra note 53, at 1373.

60. Paul Rose, Sovereigns as Shareholders, 87 N.C. L. REV. 83, 93 (2008) [hereinafter Rose, Sovereigns as Shareholders].

61. Robert M. Kimmitt, Opinion, Public Footprints in Private Markets, N.Y. TIMES (Dec. 26, 2007) http://www.nytimes.com/2007/12/26/opinion/26ihtedkimmit.html. 1373 .

62. Rose, Common Agency and the Public Corporation, supra note 53, at

63. Kimmitt, supra note 61 .

64. Id. Notwithstanding the importance of these risks, this Article focuses more narrowly on risks that SWFs pose to other investors. Some of these concerns overlap, of course. For instance, if a SWF buys assets in an effort to affect currency exchange rates, there is a potential risk of creating asset 
There are good reasons to believe in the efficacy of the existing network of regulations covering SWF investment.65 Although sovereign funds have been known to exert significant influence over some corporate decision making, 66 there is no definitive evidence that they have been used as political tools, at least with respect to sovereign fund investment in the U.S. market ${ }^{67}$ Political use of SWFs is not the only concern with SWF investment.

Other investors may not be concerned that SWFs will use their investment power to act politically but that they will instead act as "dumb money"-i.e., despite a large position in the company's stock, the SWF determines that it should act passively in order to avoid scrutiny by regulators in jurisdictions in which the SWF invests. 68 This possibility has been described as the "passive investor hypothesis" by Bortolotti, Megginson, and Votak, who show that SWF investment is associated with an initial positive reaction but then trends to negative market performance. ${ }^{69}$ This effect could be attributable to several possibilities, including suspicion over political activities by the SWF.70 Alternatively, the hypothesis

bubbles. Adrian Blundell-Wignall et al., Sovereign Wealth and Pension Fund Issues, FIN. MKT. TRENDS, 2008, at 117, 126.

65. Rose, Sovereigns as Shareholders, supra note 60, at 99.

66. Id. at 93-95.

67. There are good reasons for this, of course. The political economy of SWF investment would suggest that the investment behavior of SWFs would vary depending on the rules and political power of the country in which the SWF is investing. Id. at 133. The size of the market also plays an important factor. Imagine, for example, that a finance minister approaches an SWF manager and demands that the SWF be used for a political purpose (perhaps to invest in a particular company in order to acquire sensitive intellectual property that could be strategically useful for national security purposes). To carry out the investment, the SWF might need to engage in a series of transactions intended to conceal the source of the funds, lest the regulators in the target's home country prohibit the investor. The risk is that regulators will eventually determine the source of the funds (and the ultimate controlling entity behind the investment-the sovereign who wishes to acquire sensitive intellectual property). This risk differs significantly, however, depending on the country at issue. Suppose that the target company is in Belarus. Belarus's market is much smaller than the United States, and the costs of being shut out of that market are much smaller than being shut out of U.S. markets. In addition, Belarus may have fewer political and economic weapons, compared to the United States, that it could deploy to punish such behavior.

68. Bernardo Bortolotti, Veljko Votak \& William L. Megginson, The Sovereign Wealth Fund Discount: Evidence from Public Equity Investments, 28 REV. FIN. STUD. 2993, 2995 (2015).

69. Id. at 3017, 3025-26.

70. Bortolotti, Votak, and Megginson do find some support for this possibility, as they note that larger positions and direct influence by the SWF (for instance, by obtaining a board seat) seem to be related to poorer results. Id. at 3000-01. This is not the case for Norway's SWF, however, suggesting that 
suggests that because SWFs invest passively, they do not provide the kind of active monitoring of management that other investors expect from large institutional investors. ${ }^{71}$ As a result, SWFs risk becoming deadweight shareholders, which provide no benefit to other shareholders despite their (possibly) large holdings. Other shareholders may sell because of the managerial agency costs exacerbated by inert blockholding.

Ironically, this passivity is exactly the kind of result that would please regulators, who are not concerned so much about market performance as they are about the risk that SWFs would be used for political purposes. The Committee on Foreign Investment in the United States ("CFIUS"), 72 the most frequent and direct regulator of SWF investment in the United States, employs a fairly simple but relatively effective method of regulating SWF investment. When a foreign investor, such as a sovereign fund, decides to invest in the United States, they are generally free to do so, provided that they are not taking a controlling stake in a company that is linked to U.S. national security interests. ${ }^{73}$ CFIUS depends on the voluntary filing of notice of such a transaction with the committee, which then conducts a review of and possibly an investigation into the transaction..$^{74}$ If the transaction is deemed to create risks for U.S. national security, the transaction may be blocked (or, if it has already occurred, may be unwound). ${ }^{75}$

the governance structure of the SWF matters and, I would offer, that Norway's influence tends to reflect the interests of many other large, institutional investors.

71. Id.

72. CFIUS members are composed of the heads of the following departments and offices: Department of the Treasury (chair), Department of Justice, Department of Homeland Security, Department of Commerce, Department of Defense, Department of State, Department of Energy, Office of the U.S. Trade Representative, Office of Science \& Technology Policy. Composition of CFIUS, U.S. DEP'T TREASURY (Dec. 1, 2010, 8:08 AM), https://www.treasury.gov/resource-center/international/foreign-investment /Pages/cfius-members.aspx.

73. Rose, Sovereigns as Shareholders, supra note 60, at 99.

74. Id. at 109 .

75. This has occurred very infrequently over the course of the legislation's history: "In 1990, just two years after Exon-Florio's passage, President Bush required China National Aero-Technology Import and Export Corporation ("CATIC") to unwind its acquisition of Mamco, a Washington State-based specialty airplane component manufacturer, in order to prevent CATIC from acquiring sensitive technology ...." Paul Rose, The Foreign Investment and National Security Act of 2007: An Assessment of Its Impact on Sovereign Wealth Funds and State-Owned Enterprises 9 (Ohio State Pub. Law, Working Paper No. 231, 2014), https://papers.ssrn.com/sol3/papers.cfm?abstract_id=2387562.

In [a transaction involving the Ralls Corporation], an entity controlled by two persons alleged to have ties to the Chinese military acquired 
As noted above, whether an investment falls under the watchful gaze of CFIUS depends on whether the foreign investor acquires "control" of the U.S. entity. ${ }^{76}$ The Treasury regulations under which CFIUS operates define the term "control" fairly broadly:

[T] he power, direct or indirect, whether or not exercised, and whether or not exercised or exercisable through the ownership of a majority or a dominant minority of the total outstanding voting securities of an issuer, or by proxy voting, contractual arrangements or other means, to determine, direct or decide matters affecting an entity. ${ }^{77}$

Because engagement in corporate governance creates some risk that SWFs would be determining, directing, or deciding matters affecting an entity, U.S. law appears to create a disincentive for engagement in corporate governance. ${ }^{78}$ Thus, if a SWF invests in a U.S. company with a connection to national security-say, Boeingbut takes a minority stake and does not interfere in governance matters, it will not run afoul of the regulations enforced by CFIUS. On the other hand, if a Chinese SWF purchased eight percent of Boeing, then pressured management to build a factory in Shenzhen, the transaction would certainly draw the attention of CFIUS. But aside from such obviously problematic transactions, what if a SWF merely engages management on, for instance, its executive compensation policies? Some SWFs (and most particularly, Norway's SWF $)^{79}$ do take such an active role in governance matters, suggesting that some activities, carefully calibrated, can resolve the tension between CFIUS-driven passivity and the need to engage in corporate governance as a means to reduce managerial agency costs. 80

To clarify these issues with a question, to the extent that concerns with sovereign fund investment cannot be managed by

four wind farm project companies that operated near sensitive military and national security installations. Ralls acquired controlling interests in the wind farms in March 2012, but did not file a notice with CFIUS. Three months after the transaction closed, Ralls finally notified CFIUS of the transaction. After reviewing then investigating the transaction, CFIUS determined that mitigation was not possible, and ordered divestment. In October 2012, President Obama issued an executive order formally requiring Ralls to divest ownership of the wind farms, as well as to remove all installations, down to the concrete pads, within 14 days.

Id. at 19 n.51.

76. Rose, Sovereigns as Shareholders, supra note 60, at 99.

77. 31 C.F.R. $\S 800.204(a)$ (2017).

78. Rose, Sovereigns as Shareholders, supra note 60, at 93, 99.

79. Id. at $124-26$.

80. Id. at $125-26$. 
state-level enforcement (such as, in the United States, through the review process provided by CFIUS)-and, indeed, may be exacerbated by enforcement-what role is there for SWFs in corporate governance? And more to the point, do sovereign investors owe other investors some role in corporate governance? Do they owe other investors a role in influencing management with respect to environmental and social issues?

Although SWFs do not owe a duty to act as good corporate citizens, sovereign investors should think in terms of responsibilities they owe to other investors. The recognition of responsibilities flows from the common agency problem at the heart of SWF equity investment. ${ }^{81}$ As deep-pocketed and unusually powerful investors, SWFs present particularly strong risks to investors who share a common agent with the SWF. ${ }^{82}$ Regulation helps mitigate some of these concerns, but not all host countries have similarly robust regulations and protections for investors. ${ }^{83}$ SWF responsibility to other investors can help fill these gaps. ${ }^{84}$

This softer formulation of responsibilities rather than duties comes from a recognition that fiduciary duties must be accompanied by enforcement of those duties, if we are to take them seriously. ${ }^{85} \mathrm{~A}$ fiduciary duty without enforcement of that duty is a legal nullity, and a beneficiary of the duty has only the good heart of the fiduciary upon which to rely. ${ }^{86}$ A responsibility likewise places no enforceable legal claim in the hands of beneficiaries, and the term does not represent anything more than a moral claim. 87 But in the context of SWFs, the power of responsibilities as moral claims should not be underestimated, particularly when the fulfillment of such responsibilities reinforces the legitimacy of the sovereign entity to other investors and to its own citizens. Contrariwise, the failure to fulfill responsibilities may raise questions about the legitimacy of the sovereign entity, even if those affected are not the citizens of the sovereign itself but co-investors in a portfolio company.

The following Part first provides a framework for thinking about SWFs' responsibility as investors and then compares these principles to the primary self-regulatory structure, the Santiago Principles. As described below, the Santiago Principles help provide a basic structure for thinking about SWF responsibilities to other 1373

81. Rose, Common Agency and the Public Corporation, supra note 53, at

82. Id.

83. Rose, Sovereigns as Shareholders, supra note 60, at 127.

84. Id. at 130,134 .

85. Id. at 136 .

86. Id. at 136 n. 257.

87. Id. at 145 . 
investors but also show themselves to be a relatively weak structure even for such a modest task. It also describes how some SWFs go beyond the Santiago Principles as they provide statements of responsibility as investors through their own disclosure efforts.

\section{BASIC TENETS OF SOVEREIGN FUND INVESTMENT}

Using the idea of common agency costs as a starting point, one can derive several crucial investment principles. First, investors should be transparent in their investment purpose. This principle is particularly important (and, admittedly, perhaps only important) when the investor is able to exercise significant influence on the corporate governance and corporate decision making of the portfolio company. ${ }^{88}$ And while the principle may seem a radical departure from the principle of selfish ownership described above, such transparency of investment purpose has been a feature of U.S. federal securities laws for decades. ${ }^{89}$ Under Schedule 13D, 90 investors who acquire five percent or more of a public company's securities must disclose, among other things, their identity, basic background information, and the purpose of their investment, including any plans or proposals that would change the management of the company, its business or corporate structure, or would result in an extraordinary corporate transaction. ${ }^{91}$ Schedule 13D thus serves as an early-warning device for shareholders concerned about changes in corporate control or even corporate governance prerogatives. 92

Second, investors should be predictable in their investment behavior. This is not to say that SWFs or other investors should signal their intentions to buy or sell a particular stock, but merely that their behavior should follow the patterns suggested by their investment purpose. This is particularly true of SWFs and other

88. Id. at $144-45$.

89. Id. at 142 .

90. See Schedule 13D-Information to Be Included in Statements Filed Pursuant to $\S 240.13 \mathrm{~d}-1$ (a) and Amendments Thereto Filed Pursuant to $\S 240.13 \mathrm{~d}-2(\mathrm{a}), 17$ C.F.R. $\S 240.13 \mathrm{~d}-101$ (2017).

91. Id.

92. See Lloyd S. Harmetz \& Jared D. KaPlan, Morrison \& Foerster, Frequently Asked Questions about SeCtion 13(D) AND SECTION 13(G) OF THE SECURITIEs EXCHANGE ACT OF 1934, at 1 (2016) ("In many respects, Section 13(d) acts as an early warning, signaling 'every large, rapid aggregation or accumulation of securities, regardless of technique employed, which might represent a potential shift in corporate control." (citing GAF Corp. v. Milstein, 453 F.2d 709, 717 (2d Cir. 1971))). 
large, potentially influential investors for whom the common agency risks are much greater than for other investors. ${ }^{93}$

Finally, large investors arguably have a responsibility of presence. By that term I mean that SWFs and other large institutional investors should make their presence as engaged investors apparent to management. This is not a call for SWFs to become activist investors in the same manner as activist hedge funds that seek board seats or even operational control; indeed, doing so could create the risk that CFIUS would view the SWF as a controlling (or at least dangerously influential) shareholder and begin a review of the SWF's ownership in the portfolio company. "Presence" is, however, a call for SWFs to become engaged investors. The reason for this is simple: by remaining completely passive investors with no voice, SWFs cede the floor to other investors who are not shy about making their voices heard. ${ }^{94}$ This is a detriment not just to SWFs' beneficiaries but possibly to other investors and to corporate governance generally. 95 As institutional investors that do not have either short- or medium-term liabilities (like pension funds) and theoretically enjoy extremely long-term investment horizons (if they can be said to have any horizon at all), SWFs have unique perspectives on long-term, patient capitalism.

As entities controlled by sovereigns, SWF may also have perspectives on the long-term costs of various investment decisions, such as the negative externalities created by certain investments. To highlight this perspective, imagine an individual investor in a coal mining company. In evaluating the investment, the individual may look at potential liabilities facing the mining company-such as potential environmental suits-but only needs to consider the liabilities internalized by the company. Any negative externalities that are not ultimately charged to the company will be borne by others, including the government, and so are not priced into the investment cost.

As a final point, SWFs would benefit from network effects of a focus on reducing agency costs through transparency, predictability and presence. As large investors with significant economic stakes in many firms, SWFs also face the greatest financial risk from common

93. Rose, Common Agency and the Public Corporation, supra note 53, at 1373.

94. To put this in law school terminology, hedge funds are the "gunners" of corporate governance. As Eugene Volokh has suggested, it seems odd-and even hypocritical-for students to complain about other students "dominating the class discussion" after they failed to take the opportunity to speak. Bitter Success, Interview with Eugene Volokh, Un-American Legal Conspirator, BITTER EMPIRE: BITTER LAW. (Jan. 11, 2010), http://bitterempire.com/eugene-volokh-un -american-legal-conspirator/.

95. Rose, Sovereigns as Shareholders, supra note 60, at 120. 
agency problems caused by other large institutional investors, such as hedge funds and other SWFs.

As sovereign entities, SWFs each have their own rules, standards, and policies set out by the sovereign government. ${ }^{96}$ However, they are obviously not directly regulated by other foreign governments, except by operation of agreement, treaty, or as normal market participants would be, such as, for instance, being subject to reporting obligations regarding share ownership percentages. ${ }^{97}$ But because they are market actors while also sovereign entities with the potential conflicts outlined above, SWFs suffered (and, to some degree, perhaps still suffer) from a trust deficit. The creation of the Santiago Principles ${ }^{98}$ undoubtedly was driven in large part by the need to mitigate this trust deficit and thereby enjoy access to markets without incurring large transaction costs.99 Indeed, the introduction to the Santiago Principles makes clear that "it will be important to continue to demonstrate - to home and recipient countries, and the international financial markets-that the SWF arrangements are properly set up and investments are made on an economic and financial basis." 100 The Santiago Principles are designed to encourage trust and investment according to the following four core objectives:

96. Id. at 89 .

97. See id.

98. See generally SANTIAGo PRINCIPLES, supra note 18.

99. Transaction costs, such as may be incurred through the CFIUS process, may play a significant role in whether a SWF pursues a particular transaction: If navigating the CFIUS process requires significant expenditures of effort by the SWF and its attorneys, or if the SWF fears that the transaction may become politicized, it may choose to invest elsewhere or to limit the scope of the investment so as to avoid creating a risk that the transaction would be closely investigated by CFIUS and, possibly, ultimately blocked. Some deal-making behavior by SWFs may be characterized as a kind of regulatory arbitrage, as SWFs limit investments to ownership levels so as to avoid CFIUS filings and attention, securities regulations, or other regulations or internal governance provisions that might trigger increased costs for the SWF. Transaction costs also play another very important role in encouraging SWF passivity: they encourage SWFs to avoid appearing political in their investment and governance decisions. This may be viewed as "headline risk" for SWFs. SWFs are already viewed with suspicion by many regulators, and publicity suggesting that a sovereign is using its SWF for political purposes can have a profound effect on the costs of SWF investment; alarmist portrayals of SWF investment activity routinely ignore these headline risks and how they impact large. diversified portfolios. Rose, Sovereign Investing and Corporate Governance, supra note 2 .

100. SANTIAGo PRINCIPLES, supra note 18 , at 4. 
i. To help maintain a stable global financial system and free flow of capital and investment;

ii. To comply with all applicable regulatory and disclosure requirements in the countries in which they invest;

iii. To invest on the basis of economic and financial risk and return-related considerations; and

iv. To have in place a transparent and sound governance structure that provides for adequate operational controls, risk management, and accountability. ${ }^{101}$

There are a number of principles within the Santiago Principles that have bearing on other investors and can serve to limit common agency costs. For example, Principle 4 states that "[t]here should be clear and publicly disclosed policies, rules, procedures, or arrangements in relation to the SWF's general approach to funding, withdrawal, and spending operations." 102 Withdrawal policies may be relevant to other investors because they may be concerned with a sudden sell-off of the SWFs assets (and what that might do to the short-term price of the assets). ${ }^{103}$ Principle 15 states that "SWF operations and activities in host countries should be conducted in compliance with all applicable regulatory and disclosure requirements of the countries in which they operate."104 Investors have an interest in knowing not only that SWFs are complying with applicable regulations but, relatedly, also that regulations are enforced against SWFs to the same extent as against other investors. ${ }^{105}$

Principle 16 states that "[t]he governance framework and objectives, as well as the manner in which the SWF's management is operationally independent from the owner, should be publicly disclosed."106 Disclosure of the SWF's objectives and operational independence is important to other investors because it helps identify particular risks associated with sovereign investors (provided the disclosure is complete and accurate, of course, which is not a certainty). ${ }^{107}$ Likewise, Principle 18 also prescribes disclosure: "The SWF"s investment policy should be clear and consistent with its defined objectives, risk tolerance, and investment strategy, as set by the owner or the governing body(ies), and be based on sound portfolio management principles." 108 Investment policy disclosure

101. Id.

102. Id. at 13 .

103. Rose, Sovereigns as Shareholders, supra note 60, at 139-40.

104. SANTIAGo PRINCIPLES, supra note 18 , at 19.

105. Id.

106. Id.

107. Id.

108. Id. at 20 . 
by SWFs is generally of poor quality, with a few notable exceptions, such as the Australian Future Fund, the Alaska Permanent Fund, and Norway's Government Pension Fund Global. 109 However, it is steadily improving. ${ }^{110}$

Principle 18 calls for transparency in investment policy.111 Among other things, the policy should address the use of external managers and the SWF's financial risk exposure. SWFs vary widely in how and what they disclose regarding investment policies, with some giving detailed descriptions of risk preferences, benchmarks, and principles on how external managers are selected 112 but others providing only a bare outline of investment policies and procedures. 113

Principle 19 goes to the heart of regulators' and investors' concerns with sovereign investment. The principle states that "[t]he SWF's investment decisions should aim to maximize risk-adjusted financial returns in a manner consistent with its investment policy, and based on economic and financial grounds."114 Subprinciple 19.1. qualifies Principle 19, however, stating that "if investment decisions are subject to other than economic and financial considerations, these should be clearly set out in the investment policy and be publicly disclosed."115 To date, no SWF has stated that it makes investment decisions on a basis other than economic and financial considerations. 116 Of those two terms-"economic" and "financial"-

109. Paul Rose, Public Fund Investment Policies: 2015 Annual Review 11 (Ohio State Pub. Law, Working Paper No. 313, 2015), https://papers.ssrn.com /sol3/papers.cfm?abstract_id=2676002 [hereinafter Rose, Public Fund Investment Policies: 2015 Annual Review].

110. I have documented investment policy disclosures in several annual publications, beginning in 2014. See Paul Rose, A Disclosure Framework for Public Fund Investment Policies, 29 Procedia ECON. \& FIN. 5, 6 (2015); Rose, Public Funds Investment Policies: 2016 Survey, supra note 20, at 1-13; Rose, Public Fund Investment Policies: 2015 Annual Review, supra note 109, at 1-12.

111. SANTIAGo PRINCIPLES, supra note 18, at 20.

112. Id. at $20-21$.

113. Id. at 21 .

114. Id. at 22 .

115. Id.

116. A recent survey of SWF self-assessments of compliance with the Santiago Principles indicates that several SWFs have disclosed certain economic considerations with which they are required to comply:

Most IFSWF members invest to maximise risk-adjusted returns subject to their investment policy. Because the primary objective of most funds is wealth management and growth, this objective is consistent with their mandate to grow the wealth of the fund. Several funds have a discrete economic or development mandate in addition to an objective to generate solid financial performance. Ireland's ISIF, Italy's CDP Equity, the RDIF in Russia, and the Palestine Investment 
"economic" is the more problematic if we believe, as Romberg states, that "all economics is political."117 At the very least, however, disclosure by a SWF that it is going to act for strategic economic (or political) reasons would provide other investors some information needed to evaluate the risk and discount their investments accordingly.

Under Principle 20, SWFs are admonished that they "should not seek or take advantage of privileged information or inappropriate influence by the broader government in competing with private entities." 118 SWFs (or at least their government sponsors) have not only informational advantages by virtue of their communications with other government officials and regulators but also the ability to create informational advantages. ${ }^{119}$ For instance, a SWF may invest in company $A$, then, in concert with other governmental actors, could conceivably bring a regulatory action against a competitor, company $B$, or otherwise bar them from the SWF's home markets, effectively driving down the price of company $B$ and perhaps boosting the price of company $A$. The SWF's knowledge of these impending actions could enable them to both profit on a long position in company $A$ and a short position in company $B$.

Finally, Principle 21 states that

SWFs view shareholder ownership rights as a fundamental element of their equity investments' value. If an SWF chooses to exercise its ownership rights, it should do so in a manner that is consistent with its investment policy and protects the financial value of its investments. The SWF should publicly disclose its general approach to voting securities of listed entities, including the key factors guiding its exercise of ownership rights. 120

Although many SWFs are relatively passive when exercising their shareholder rights, ${ }^{121}$ some have been active both in merger negotiations (such as Qatar's involvement in Glencore's bid for

Fund all share such a mandate, as does one of the sub-funds of Nigeria's NSIA.

Trends in Transparency: Santiago Principle Self-Assessments 2016, INT'L F. SOVEREIGN WEALTH FUNDS, http://www.ifswf.org/trends-transparency-santiago -principle-self-assessments-2016 (last visited Oct. 25, 2017).

117. Alan D. Romberg, All Economics Is Political: ECFA Front and Center, 32 CHINA LEADERSHIP MONITOR, Spring 2010, at 1, 13.

118. SANTIAGo PRINCIPLES, supra note 18, at 22.

119. Id.

120. Id.

121. Id. at 23 . 
Xstrata ${ }^{122}$ ) or they have engaged in extensive discussion with portfolio companies over matters of corporate governance (such as Norway's Government Pension Fund Global's focus on executive compensation).123 Again, there is no evidence that SWFs have used their shareholder power in a way that is inconsistent with Principle 21 , at least with respect to their investments in Western markets. This may have to do as much with the risks of doing so (such as the political risk of upsetting a politically powerful host country and the higher transaction costs necessary to access those markets after inappropriate investment behavior), as it does with SWFs affirmatively determining to comply with Principle 21 .

To summarize these guidelines, the Santiago Principles encourage SWFs to be independent from political interference by the sponsor government, apolitical (or, at least, disclose if the SWF is not going to be), law abiding, and otherwise consistent with a financial orientation that seeks to maximize risk-adjusted financial gains. ${ }^{124}$ SWFs show a wide variety of approaches both in how they govern themselves and how-or even whether-they disclose their policies. ${ }^{125}$ This variability makes managing common agency costs somewhat challenging. Although most funds behave in relatively stable ways with respect to the exercise of shareholder rights, ${ }^{126}$ for example, the differences in approaches means that other investors cannot rely on SWFs to fit a particular model of behavior. In other words, some SWFs may behave like mutual funds, which tend not to be engaged in governance for a variety of reasons, while others may behave like public pension funds, which tend to be more willing to engage on matters of governance. ${ }^{127}$

122. One report noted: "It is therefore something of a watershed moment when an SWF acts like an activist shareholder, which is precisely what Qatar did when it rejected Glencore's offer. 'The transformation was likely inevitable once the sovereign wealth funds began to invest directly in companies,' says Leonard Schneidman, Managing Director of WTAS, a tax, valuation and financial advisory firm. "They can no longer work solely behind the scenes or pursue their objectives via intermediary entities,' adds Schneidman." Richard Levick, Game-Changer: Qatar Plays Historic Role in Glencore's Bid for Xstrata, FORBES (Sep. 12, 2012, 7:23 AM), https://www.forbes.com/sites/richardlevick /2012/09/12/game-changer-qatar-plays-historic-role-in-glencores-bid-for-xstrata \#184cfc40607b. Contra Rose, Sovereign Investing and Corporate Governance, supra note 2, at 945-46 (offering a different view on whether Qatar was really an "activist" investor or simply an engaged shareholder trying to make sure it received a fair deal).

123. Norway's Sovereign Fund to Focus on High Executive Pay: FT, REUTERS (May 1, 2016, 6:23 PM), http://www.reuters.com/article/us-norway-swf -idUSKCNOXS1MO.

124. SANTIAGO PRINCIPLES, supra note 18, at 23.

125. Id.

126. Id.

127. The SovereigNET/IFSWF report on self-assessments notes that 


\section{HOW EFFECTIVE ARE SWFS IN COMPLYING WITH COMMON AGENCY COST-REDUCING SANTIAGO PRINCIPLES?}

In this Part, the Article reviews how three different SWFs have assessed their own compliance with the Santiago Principles. Again, this is important to show how SWFs impact common agency costs because, as noted above, the Santiago Principles serve as a means to limit common agency costs insofar as they encourage transparency and predictability. ${ }^{28}$ If the good news is that some of the common agency concerns raised by sovereign investment may be mitigated by the Santiago Principles, the bad news is that most funds do a poor job in complying with them, at least in terms of what they disclose. ${ }^{129}$ In general, the self-assessments reaffirm the concern noted earlier: SWFs vary widely in their governance practices and in how and what they disclose. ${ }^{130}$

\section{A. Abu Dhabi Investment Authority}

The Abu Dhabi Investment Authority ("ADIA") is one of the largest SWFs in the world, boasting nearly $\$ 800$ billion in assets. 131 In the fund's recent self-assessment, ADIA provided extensive disclosures on how it complies with the Santiago Principles. ${ }^{132}$

When describing who "owns" the fund, ADIA discloses that "the natural resources and wealth... are the public property of Abu Dhabi."133 ADIA's Investment Services Department ensures adherence to local laws and disclosure requirements as well as

[m]ost funds exercise voting rights directly as shareholders for economic and financial reasons. Of these funds, the Future Fund, CIC, NZSF, the RDIF, and Alaska's APF each share publicly how they exercise shareholder rights. ADIA reports that it does not exercise voting rights unless it believes it must protect its financial interests or those of shareholders as a body. SOFAZ and Chile's SWFs indicate that they do not exercise shareholder rights or they take a neutral position. Mexico's BSIF and PIF in Palestine do not have shareholder policies. In Trinidad and Tobago, the HSF does not disclose its policy, while Botswana and Nigeria's sovereign funds rely on their external managers to exercise voting rights by proxy.

Trends in Transparency: Santiago Principle Self-Assessments 2016, supra note 116.

128. They do not, however, encourage "presence," as some SWFs may feel that excessive engagement may actually trigger regulatory scrutiny. Id.

129. Id.

130. Id.

131. See Fund Rankings, SWFI, http://www.swfinstitute.org/fund-rankings/ (last visited Oct. 25, 2017).

132. Santiago Principles Self-Assessment: Abu Dhabi Investment Authority, INT'L F. SOVEREIGN WEALTH FUNDS, http://www.ifswf.org/assessment/adia (last visited Oct. 25, 2017).

133. Id. 
supports ADIA in exercising shareholder rights and obligations, including voting rights. ${ }^{134}$ The fund also provides an annual report, discloses its investment objectives, and publicly discloses how ADIA is operationally independent from political control. ${ }^{135}$

ADIA's self-assessment is laudable in its extensive discussion of investment policy, asset allocation, and external management selection. ${ }^{136}$ The fund also describes how its investment decisions are based "solely on its economic objectives of delivering sustained long-term financial returns and aims to maximize risk-adjusted financial returns." 137

Finally, ADIA explains how, because it is independent from the government, it has no access to privileged information. ${ }^{138}$ In its discussion of compliance with Principle 21, it notes that it "exercises its voting rights ... to protect its interests or to oppose motions that may be detrimental to shareholders as a body."139 It does not attempt to control or inappropriately influence portfolio companies and has a practice of avoiding active management of portfolio companies. ${ }^{140}$ ADIA makes appropriate ex ante disclosures related to stock trading as well as ex post disclosures related to investment thresholds, all of which assist other investors in assessing the risks ADIA may pose as a co-investor sharing a common agent. ${ }^{141}$

\section{B. China Investment Corporation}

China Investment Corporation is another of the largest SWFs in the world, also with over $\$ 800$ billion in assets. ${ }^{142}$ In comparison to ADIA's disclosure, CIC's is much sparser. CIC notes that it is a "responsible investor" that abides by the laws of China and recipient countries and conscientiously fulfills corporate social responsibilities. ${ }^{143}$ The fund also notes that its "approach to exercise shareholder ownership rights is consistent with its investment principles as mentioned above and aims to protect and maximize its financial interests of its investments." 144

134. Id.

135. Id.

136. Id.

137. Id.

138. Id.

139. Id.

140. Id.

141. Id.

142. See Fund Rankings, supra note 131.

143. Santiago Principles Self-Assessment: China Investment Corporation, INT'L F. SOVEREIGN WEALTH FUNDS, http://www.ifswf.org/assessment/cic (last visited Oct. 15, 2017).

144. Id. 
As a general matter, CIC's self-assessment does not provide much disclosure itself but instead refers to existing documents, such as its annual report. ${ }^{145}$ However, despite the fact that CIC's annual report is a sophisticated, glossy publication, it does not provide much detail on the inner workings of the fund; even incorporating all of CIC's disclosures by reference, CIC's disclosures provide little that would help other investors assess CIC's risk as a co-principal. ${ }^{146}$ This is especially problematic because CIC may be viewed by some investors as presenting greater risks as a common principal. ${ }^{147}$ As a primary economic and political rival to the United States, there is a risk that CIC's investments may be politicized by U.S. regulators and, potentially, a risk that CIC could be used for political purposes by China. ${ }^{148}$ The same may be said of other regulators and the CIC's investments in Europe, Africa, and Asia.

\section{Australia Future Fund}

Like ADIA, the Australia Future Fund provided extensive disclosures; indeed, the disclosures were as detailed as any selfassessment. ${ }^{149}$ The Future Fund provided extensive discussion of the fund's governance structures; how investment decisions are made; the fund's approach to environmental, social, and governance issues; the type of investments the fund will and will not consider; and the fund's obligation to act as a prudent investor that seeks to maximize risk-adjusted returns. ${ }^{150}$

While most funds rightly try to demonstrate independence from politics, the Future Fund recognizes that even if it acts apolitically, it still operates as a sovereign fund whose behavior reflects on the Australian government.151 To that effect, the self-assessment discloses that "legislation requires the Board of Guardians to act in a way that is unlikely to cause any diminution of the Australian Government's reputation in international financial markets."152

The Future Fund also responds to common agency concerns in a very direct way by providing a detailed statement of ownership and voting-rights expectations as well as reporting on how voting rights have been exercised. 153

145. Id.

146. Id.

147. Id

148. Id.

149. Santiago Principles Self-Assessment: Future Fund, INT'L F. SOVEREIGN WEALTH FUNDS, http://www.ifswf.org/assessment/future-fund last visited Oct. $15,2017)$.

150. Id.

151. Id.

152. $I d$.

153. Id. 


\section{CONCLUSION}

What do sovereign investors owe to other investors? This Article suggests that although in most cases SWFs do not owe direct duties to other investors, SWFs can limit the common agency costs faced by other investors by providing adequate disclosures and behaving predictably. Additionally, as large investors that often control significant blocks of shares, SWFs should accept a responsibility to be engaged, active investors. As noted above, this is not a call to be an activist in a way that would trigger a review by regulators such as CFIUS but simply a call to defend the interests of other long-term investors and the governments and citizens for whom the fund is operated. Common agency costs are a part of modern corporate governance; hedge funds, for example, will often invest in a company in order to pressure it to pay a dividend, split off a division, merge with another entity, or otherwise provide a liquidity event for investors. ${ }^{154}$ In some cases, these decisions may have a detrimental effect on the long-term prospects of the company. 155 Rather than being inert, "dumb money," SWFs can add their voice to these important, strategic discussions.

The Santiago Principles provide a framework for SWFs to disclose important aspects of their governance and investment processes and thereby limit common agency costs. Too often, however, SWFs fail to fully embrace the call for transparency set out in the Santiago Principles. As evidenced by the recent selfassessments provided by a large number of SWFs, some funds provide detailed disclosures that help reduce potential common agency costs. Others, however, simply provide a "check-the-box" disclosure that leaves many questions unanswered. Although the self-assessments of a handful of SWFs show them to be transparent, predictable, and present in corporate governance matters, they also put in stark relief the relative deficiencies of many other SWFs.

154. See Martin Lipton, Dealing with Activist Hedge Funds and Other Activist Investors, HARV. L. SCH. F. ON CORP. GOvernanCE \& FIN. REg. (Jan. 26, 2017), https://corpgov.law.harvard.edu/2017/01/26/dealing-with-activist-hedge -funds-and-other-activist-investors/.

155. See id. 